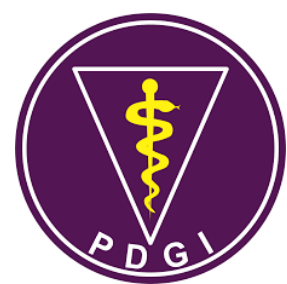

\title{
Antibiofilm Effect of Clitoria ternatea Flower Juice on Porphyromonas gingivalis in vitro
}

\author{
Armelia Sari Widyarman ${ }^{1 \S}$, Stephani Sumadi ${ }^{2}$, Tri Putriany Agustin ${ }^{3}$ \\ ${ }^{1}$ Department of Microbiology, Faculty of Dentistry, Trisakti University, Indonesia \\ 2 Undergraduate student, Faculty of Dentistry, Trisakti University, Indonesia \\ ${ }^{3}$ Pediatric Dentistry, Faculty of Dentistry, Trisakti University, Indonesia
}

Received date: September 2, 2018. Accepted date: September 28, 2018. Published date: October 19, 2018

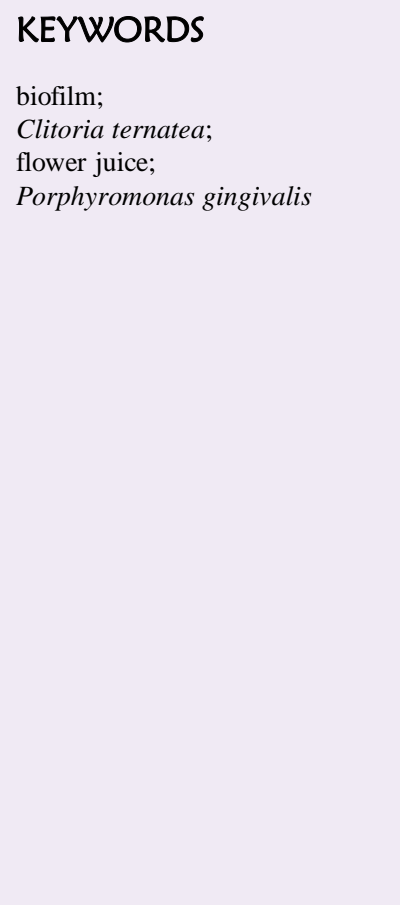

\begin{abstract}
Introduction: Clitoria ternatea flower contains flavonoid such as anthocyanin that gives the blue color to its flower and has antimicrobial activity. Objectives: The aim of this study was to examine the effect of flower juice of Clitoria ternatea against Porphyromonas gingivalis biofilm viability in vitro. Methods: This study was experimental laboratory research using biofilm assay method. $P$. gingivalis was cultured in BHI broth in $37^{\circ} \mathrm{C}$ for $24 \mathrm{~h}$ under anaerobic condition. Fresh flowers of Clitoria ternatea were extracted using mortar and pestle and diluted into 6 different concentrations: $100 \%, 50 \%, 25 \%, 12.5 \%, 6.25 \%$, and $3.125 \%$ with phosphate buffer saline (PBS). Chlorhexidine $(0.2 \%)$ was used as positive control and biofilm without treatment as negative control. The flower juice was distributed into 96 well-plates that contained biofilm of $P$. gingivalis and incubated for $1 \mathrm{~h}, 3 \mathrm{~h}, 6 \mathrm{~h}$, and $24 \mathrm{~h}$ in $37^{\circ} \mathrm{C}$, anaerobic atmosphere. Biofilm was measured using crystal violet dye with microplate reader $(490 \mathrm{~nm})$. Data were statistically analysed using one-way ANOVA test and Post Hoc test with $\mathrm{p}<0.05$ was set as significant different. Result: Result showed that Clitoria ternatea flower juice significantly reduced the Porphyromonas gingivalis biofilm viability in all concentration and all incubation time. The most effective concentration to inhibit Porphyromonas gingivalis biofilm was $100 \%$ in $1 \mathrm{~h}$ incubation time which biofilm was diminished (Optical Density $=0.00$ ). One way ANOVA test and Post Hoc test showed a significant biofilm reduction in all concentration and all incubation time after treatment with the flower juice compared to control $(\mathrm{p}<0.05)$. Conclusion: Clitoria ternatea flower juice has antibiofilm effect against Porphyromonas gingivalis. This result showed this flower juice may be useful for combating periodontal pathogens. However, further studies using other bacteria are still needed to confirm this result.
\end{abstract}




\section{INTRODUCTION}

The most common dental and oral diseases in the Indonesian population are dental caries and periodontal disease. ${ }^{1}$ Periodontitis is a chronic disease caused by an inflammatory response of the dental supporting tissue to microbial biofilms (dental plaque). ${ }^{2}$ This inflammatory response can damage dental attachment apparatus (i.e., gingiva, cementum, periodontal ligaments, and alveolar bone). If left untreated, periodontitis can cause tooth loss. ${ }^{3}$ A recent study pointed to a possible association of periodontitis with systemic diseases, such as cardiovascular disease, diabetes, renal disease, respiratory dysfunction, rheumatoid arthritis, osteoporosis, and premature/low weight newborns. ${ }^{4}$

Periodontal disease is one of a number of oral infections initiated by biofilm formation. ${ }^{5}$ These biofilms consists of bacteria that adhere to polysaccharide matrices and other organic and inorganic materials. ${ }^{6}$ In the early stages of biofilm formation, the bacterial colony is dominated by aerobic bacteria (Streptococcus mutans and Sreptococcus sanguis). As the biofilm grows, it is dominated by anaerobic bacteria (Aggregatibacter actinomycetemcomitans and Porphyromonas gingivalis). ${ }^{7}$ The biofilm is resistant to other microorganisms, the host's defenses, and toxic substances, such as chemicals and antibiotics. ${ }^{6}$

Anaerobic bacteria, such as Aggregatibacter actinomycetemcomitans, Porphyromonas gingivalis, Bacteroides forsythus, and Treponema denticola, play an important role in periodontitis. ${ }^{8}$ The aim of periodontitis treatment is to improve periodontal health, including reducing anaerobic bacteria colonies in dental plaque. ${ }^{2}$ Although such treatment usually involves only plaque and calculus removal, local or systemic antibiotics can help treat periodontal disease, especially among patients with recurrent periodontitis. ${ }^{9}$

Natural ingredients can be used as an alternative treatment for periodontal disease. The popularity of natural ingredients has increased due to their ready availability, low cost, and minimal side effects. ${ }^{10}$ They are also environmentally friendly. Many studies have investigated the ability of herbal or fruit juice to inhibit oral pathogens and biofilm formation. ${ }^{11-13}$ In terms of natural ingredients, components of Clitoria ternatea or the telang flower have been used. This plant belongs to the vine family and is often used as decoration or medicine. C. ternatea is found on Ternate island, Indonesia as well as in many countries in southeast Asia, such as India, Bangladesh, and Malaysia. In Indonesia, especially in West Java, the flower parts of the plant are often soaked in hot water to make a drink, which has many uses, including stomatitis treatment. The flower parts are also used to prepare an eye drop treatment for red eye and conjungtivitis. ${ }^{14}$

C. ternatea has been known for its property as antiinflammatory, antipyretic, and analgesic. ${ }^{15}$ The root of the plant contains a flavonol glycoside, which has a strong antibacterial effect. ${ }^{16}$ The flower and seed parts of C. ternatea contain an active peptide compound, cliotide, which functions as a strong antimicrobial agent. ${ }^{17} \mathrm{~A}$ previous study showed that $C$. ternatea exerted a strong antimicrobial effect against various pathogenic bacteria, such as Escherichia coli, Vibrio cholera, and Staphylococcus aureus, thereby making it an effective treatment for many infectious diseases. ${ }^{10}$ Flowers from $C$. ternatea contain methanol, chloroform, petroleum ether, hexane, and aqueous. ${ }^{15}$ Despite the beneficial properties of C. ternatea, very few studies have examined its potential against pathogenic bacteria in the oral cavity. Therefore, the aim of this study was to investigate the effect of $C$. ternatea flower juice against biofilms of $P$. gingivalis.

\section{MATERIAL AND METHODS}

\section{P. gingivalis Culture}

P. gingivalis ATCC 33277 was cultured using brain heart infusion (BHI) broth at $37^{\circ} \mathrm{C}$ for $24 \mathrm{~h}$ under anaerobic conditions in a GasPak jar system. ${ }^{18}$

\section{C. ternatea Extract}

The flowers of $C$. ternatea were used in this research. The flowers were separated from the pod until only the petals were left. The petals were then washed until clean under running water. The moistened petals were then crushed using a mortar and pestle until the juice extract of $C$. ternatea was obtained. Subsequently, the juice extract was diluted into five different concentration $(100 \%, 50 \%, 25 \%, 12.5 \%, 6.25 \%$, and $3.125 \%$ ) using phosphate buffer saline (PBS).

\section{Biofilm Assay}

The effect of the flower juice extract on $P$. gingivalis ATCC 33277 was analyzed using a biofilm assay with crystal violet dye. For the bioassay, $200 \mu \mathrm{L}$ of $P$. gingivalis $\left(1.5 \times 10^{8} \mathrm{CFU} / \mathrm{mL}\right.$ were inoculated into 96 well-plates and incubated for $2 \times 24 \mathrm{~h}$ at $37^{\circ} \mathrm{C}$ under anaerobic conditions to encourage biofilm growth. After $48 \mathrm{~h}$, the well plates were rinsed with phosphate buffer saline (PBS). The growing biofilms were treated with different concentrations $(100 \%, 50 \%, 25 \%, 12.5 \%$, $6.25 \%$, and $3.125 \%$ ) of C. ternatea flower juice extract. As a positive control, a culture was treated with chlorhexidine $(0.2 \%)$. Untreated culture in BHI broth was used as a negative control. The inhibitory effect of the juice was observed after $1 \mathrm{~h}, 3 \mathrm{~h}, 6 \mathrm{~h}$, and $24 \mathrm{~h}$ incubation. 
After each incubation period, the $C$. ternatea juice was removed, and the well plates were rinsed twice with PBS. Crystal violet dye $(0.05 \%)$ was then added to the well plates and incubated for $15 \mathrm{~min}$. Subsequently, $200 \mu \mathrm{L}$ of $90 \%$ ethanol were added, and a microplate reader was used to determine the optical density (OD) at a wavelength of $490 \mathrm{~nm}$.

Additionally, the velocity of biofilm formation of non-treated groups was observed $6,24,48$, and $72 \mathrm{~h}$ using the formula below:

$$
\mathrm{BF}=\mathrm{AB}-\mathrm{CW} ; \mathrm{BF}=\mathrm{AB} / \mathrm{CW} ; \mathrm{SBF}=(\mathrm{AB}-\mathrm{CW}) / \mathrm{G}
$$

where $\mathrm{BF}$ denotes biofilm formation, $\mathrm{AB}$ denotes the optical density at $600 \mathrm{~nm}\left(\mathrm{OD}_{600 \mathrm{~nm}}\right)$ of the stained bacteria, $\mathrm{CW}$ denotes the $\mathrm{OD}_{600 \mathrm{~nm}}$ of the bacterial medium, SBF is the specific biofilm formation, and $\mathrm{G}$ signifies the bacterial growth in culture at $\mathrm{OD}_{600 \mathrm{~nm}} \cdot{ }^{21}$

\section{Statistical Analysis}

The data was statistically analyzed using a one-way ANOVA test and a Post Hoc LSD test in which p $<0.05$ was set as the significant difference. The KolmogorovSmirnov test was used previously as data normality test.

\section{RESULTS}

The $C$. ternatea flower juice extract significantly reduced $P$. gingivalis biofilm mass in all incubation period $(\mathrm{p}<0.05)$. The $C$. ternatea extract at a concentration of $100 \%$ had the highest inhibitory effect on $P$. gingivalis $1 \mathrm{~h}$ post incubation period, with $\mathrm{OD}$ value of $0.004 \pm 0.031$. There were significant differences compared to the negative control, with an OD value of $0.379 \pm 0.038(p<0.05)$ as shown in Fig.1. At $3 \mathrm{~h}$ post incubation period, the most effective concentration was $50 \%$, with an OD value of $0.398 \pm 0.115$ (Fig.2).

The results showed that the $C$. ternatea extract at a $50 \%$ concentration had the highest inhibitory effect on $P$. gingivalis biofilm formation after $6 \mathrm{~h}$ of incubation, with an OD value $0.472 \pm 0.145$ as compared with that of the negative control (OD value: $1.27 \pm 0.219$ ) (Fig. 3). As shown in Fig.4, at 24h post incubation, the C. ternatea extract inhibited $P$. gingivalis biofilm formation, with the smallest OD value $(0.117 \pm 0.079)$ at a concentration of $100 \%$.

Table 1 showed the results of the velocity measurements of biofilm formation. The OD values 6 , 24,48 , and $72 \mathrm{~h}$ post incubation were $1.089 \pm 4.685$, $0.913 \pm 5.340, \quad 2.089 \pm 7.026, \quad$ and $1.672 \pm 5.429$, respectively. The OD values for SBF were $2.563,2.148$, 4.797, and 3.943 after $6,24,48$, and $72 \mathrm{~h}$ of incubation, respectively.

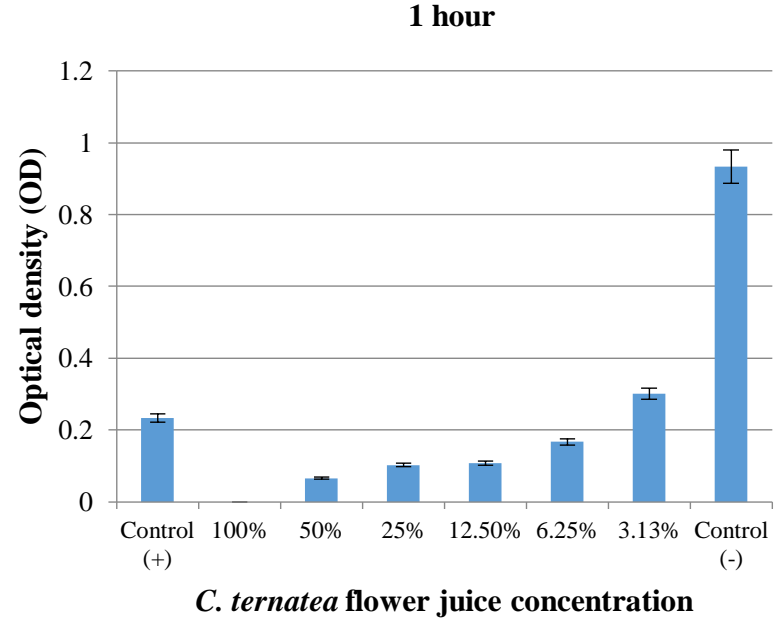

Figure 1. Graphic of the inhibitory effect of $C$. ternatea flower juice extract on $P$. gingivalis biofilm formation after 1 hour post-incubation.

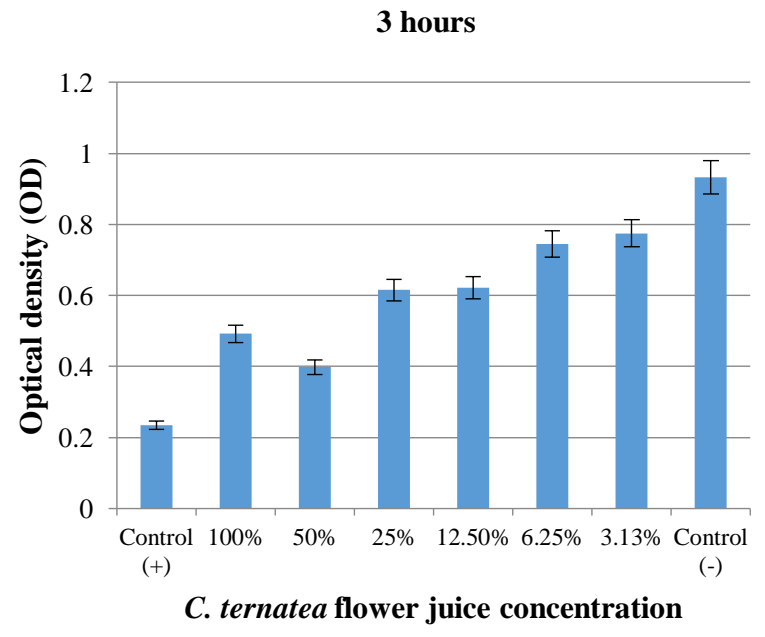

Figure 2. Graphic of the inhibitory effect of $C$. ternatea flower juice extract on $P$. gingivalis biofilm formation after 3 hours post-incubation.

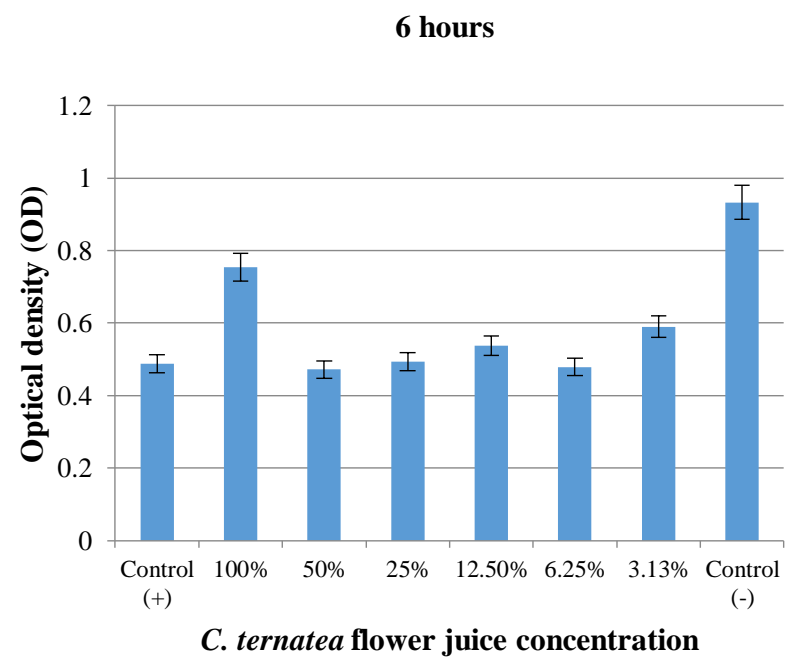

Figure 3. Graphic of the inhibitory effect of C. ternatea flower juice extract on $P$. gingivalis biofilm formation after 6 hours post-incubation. 


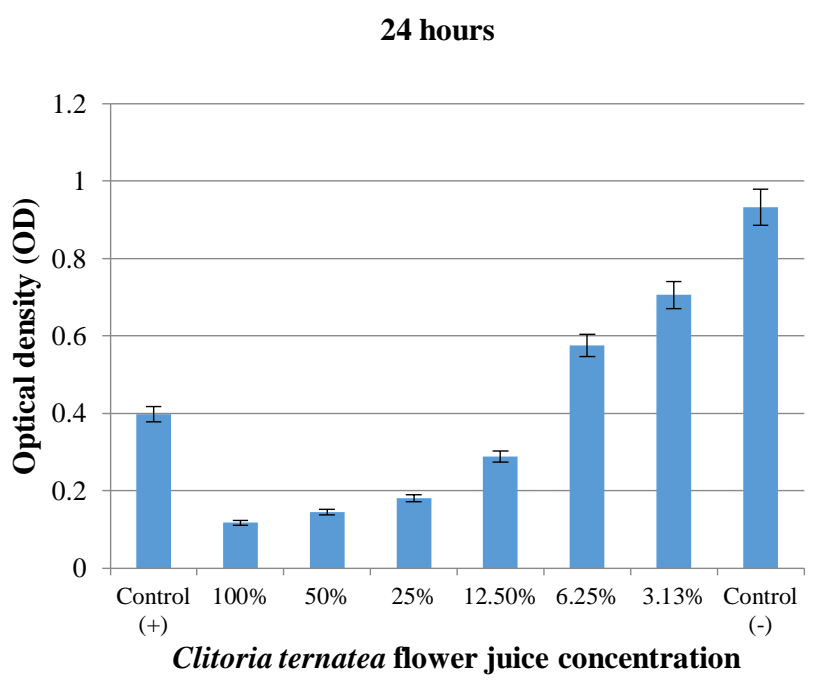

Figure 4. Graphic of the inhibitory effect of $C$. ternatea flower juice extract on $P$. gingivalis biofilm formation after 24 hours post-incubation.

Table 1. The velocity of biofilm formation

\begin{tabular}{lcccc}
\hline \multicolumn{1}{c}{ Variables } & $\mathbf{6 h}$ & $\mathbf{2 4 h}$ & $\mathbf{4 8 h}$ & $\mathbf{7 2 h}$ \\
\hline $\mathrm{BF}=\mathrm{AB}-\mathrm{CW}$ & 1.089 & 0.913 & 2.039 & 1.672 \\
$\mathrm{BF}=\mathrm{AB} / \mathrm{CW}$ & 4.685 & 5.340 & 7.026 & 5.429 \\
$\mathrm{SBF}=(\mathrm{AB}-\mathrm{CW}) / \mathrm{G}$ & 2.563 & 2.148 & 4.797 & 3.934 \\
\hline
\end{tabular}

BF: biofilm formation; $\mathrm{AB}: \mathrm{OD}_{600 \mathrm{~nm}}$ of the stained bacteria; $\mathrm{CW}: \mathrm{OD}_{600 \mathrm{~nm}}$ of the bacterial medium; SBF: specific biofilm formation; G: bacterial growth in culture at $\mathrm{OD}_{600 \mathrm{~nm}}$.

\section{DISCUSSION}

The $C$. ternatea plant is used as a traditional herbal medicine in Indonesia. Although all parts of the plant can be used, the flower parts are most commonly used due to their antimicrobial, anti-inflammatory, and antioxidant properties. ${ }^{22}$ As the potential benefits of parts of the $C$. ternatea plant in oral health are not well known, the present study examined the effect of $C$. ternatea flower juice extract on biofilm formation of the pathogenic bacterium $P$. gingivalis. $P$. gingivalis can adhere to hard surfaces or intraoral mucosa, and it plays an important role in chronic and aggressive periodontitis. ${ }^{23}$

Previous research showed that the $C$. ternatea flower inhibited the growth of pathogenic bacteria, such as $S$. mutans, Lactobacillus casei, and S. aureus, in the oral cavity. ${ }^{10} C$. ternatea also inhibited the growth of Gramnegative bacteria, such as Escherichia coli and Candida albicans. ${ }^{24}$ The flower petals of C. ternatea contain anthocyanins, which are responsible for the color of the petals. Anthocyanins are polar particles that dissolve in water, ethanol, methanol, and other polar dissolvents ${ }^{25}$ and have antioxidant, antimicrobial, and antiinflammatory properties. ${ }^{26,27}$

As shown by the formula used to calculate the speed of biofilm formation, it was rapid at all the post incubation times measured. According to the formula, $P$. gingivalis biofilm formation at all the incubation times with $\mathrm{BF}=\mathrm{AB}-\mathrm{CW}$, the category was strong $(\mathrm{OD}>0.30)$ for this bacterium. With $\mathrm{BF}=\mathrm{AB} / \mathrm{CW}$, after 6,24 , and $72 \mathrm{~h}$, the category was moderate $(4.00<\mathrm{OD}<5.99)$. After $48 \mathrm{~h}$ of incubation, the category was strong $(\mathrm{OD} \geq 6.00)$. With $\mathrm{SBF}=(\mathrm{AB}-\mathrm{CW}) / \mathrm{G}$, at all the incubation times, the category was strong $(\mathrm{OD} \geq 1.10)$.

The inhibition of biofilm formation was greatest at C. ternatea flower juice extract concentrations of $100 \%$ and $50 \%$ due to the presence of increased amounts of anthocyanins, which are flavonoids with antibiofilm activity. The effective incubation time period in inhibit biofilm in this study was $24 \mathrm{~h}$ which biofilm begin the maturation phase. A previous study showed that anthocyanins affected the growth of Gram-negative bacteria, such as $E$. coli, by inhibiting the production of fimbriae, which are required by bacteria to form biofilms. ${ }^{28}$ Research also demonstrated that anthocyanins inhibit $P$. gingivalis and the activity of gingipains, which are $P$. gingivalis virulence factors. ${ }^{29}$ Although anthocyanin shows activity against many microbes, Gram-positive bacteria are more sensitive to anthocyanin than Gram-negative bacteria. Gram-negative bacteria have an outer membrane, which functions as a permeability barrier and impedes the absorption of compounds. ${ }^{27}$

Another study showed that $C$. ternatea extracts contain tannin, phlobatannin, flavonoid, antharaquinone, alkaloid, saponin, cardiac glycosides, volatile oils, steroids and terpenoids. ${ }^{30}$ Flavonoid, inhibited the membrane function and penetrated the lipid bilayer of bacteria, thereby destroying the barrier function of the outer membrane. ${ }^{31}$ Furthermore, this compound caused membrane fusion, which resulted in cell leakage. However, the compound showed less success in terms of penetrating the lipopolysaccharide membrane of Gramnegative bacteria. $^{32}$ Therefore, its antibacterial mechanism is limited. In another study, the flavonoid inhibited bacterial energy metabolism required for the synthesis of macromolecules (DNA, RNA, and protein)..$^{33}$

A previous study showed antimicrobial activities of the methanol extracts of the leaf, stems, flower, seed, and 
roots of $C$. ternatea against 12 bacterial species, 2 yeast species, and 3 filamentous fungal by the agar diffusion and broth dilution methods. ${ }^{30}$ These results confirmed the effectiveness of $C$. ternatea in the inhibition of the growth of pathogenic microorganism. In a study in which C. ternatea extract was obtained using the maceration method with water, methanol, and chloroform, the extract showed antimicrobial activity against Escherichia coli, Salmonella typhimurium, Klebsiella pneumonia, and Pseudomonas aureginosa. ${ }^{17}$

\section{CONCLUSION}

C. ternatea flower juice extract exerted an antibiofilm effect on $P$. gingivalis. The results suggested that the extract may be useful in combating periodontal pathogens. Further studies examining the effect of the extract against other bacteria are needed to confirm these results.

\section{ACKNOWLEDGEMENT}

Authors would like to thank Dr. Erni Erfan for her help providing the $C$. ternatea flower. Authors also would like to thank MiCORE Laboratory, Faculty of Dentistry Trisakti University for their support for this study.

\section{CONFLICT OF INTEREST}

The authors declare that there are no conflicts of interest.

\section{REFERENCES}

1. Hamadi DA, Gunawan PN, Mariati NW. Gambaran pengetahuan orang tua tentang pencegahan karies dan status karies murid SD Kelurahan Mendono Kecamatan Kintom Kabupaten Banggai. Jurnal eGiGi. 2015;3(1):7-12.

2. Loesche WJ, Grossman NS. Periodontal disease as a specific, albeit chronic, infection: diagnosis and treatment. Clin Microbiol Rev. 2001;14:727-52.

3. Guthmiller JM, Novak KF. Periodontal diseases. ASM Press, 2002. Available at: https://www.ncbi.nlm.nih.gov/books/NBK2496/ (accessed 1 Oct 2018).

4. Otomo-Corgel J, Pucher JJ, Rethman MP, Reynolds MA. State of the science: chronic periodontitis and systemic health. J Evid Based Dent Pract. 2012;12 Suppl 3:20-8.

5. Vieira Colombo AP, Magalhães CB, Hartenbach FARR, Martins do Souto R, Maciel da SilvaBoghossian C. Periodontal-disease-associated biofilm: a reservoir for pathogens of medical importance. Microb Pathog. 2016;94:27-34.
6. Chandki R, Banthia P, Banthia R. Biofilms: a microbial home. J Indian Soc Periodontol. 2011;15: $111-4$.

7. Lazar V, Ditu L-M, Curutiu C, Gheorghe I, Holban A, Chifiriuc MP and C. Impact of dental plaque biofilms in periodontal disease: management and future therapy. Periodontitis - Useful Ref. 2017. doi:10.5772/intechopen.69959.

8. Kapoor A, Malhotra R, Grover V, Grover D. Systemic antibiotic therapy in periodontics. Dent Res J. 2012; 9: 505-15.

9. Mombelli A, Samaranayake LP. Topical and systemic antibiotics in the management of periodontal diseases. Int Dent J. 2004;54:3-14.

10. Gowd MJSP, Kumar MM, Shankar AS, Sujatha B, Sreedevi E. Evaluation of three medicinal plants for anti-microbial activity. AYU Int Q J Res Ayurveda. 2012;33(3):423-8.

11. Widyarman AS, Widjaja SB, Idrus E. Strawberry extract's effects on Enterococcus faecalis and Porphyromonas gingivalis biofilms in vitro. Sci Dent J. 2017;1(1):1-5.

12. Liliany D, Widyarman AS, Erfan E, Sudiono J, Djamil MS. Enzymatic activity of bromelain isolated pineapple (Ananas comosus) hump and its antibacterial effect on Enterococcus faecalis. Sci Dent J 2018;2(2):39-50.

13. Widyarman AS, Suhalim OP, Nandary D, Theodorea CF. Pomegranate juice inhibits periodontal pathogens biofilm in vitro. Sci Dent J. 2018;2(3):101-8.

14. Djunarko I, Manurung DYS, Sagala N. Efek antiinflamasi infusa bunga telang (Clitoria ternatea L.) dan kombinasi dengan infusa daun iler (Coleus atropurpureus L. Benth) dosis $140 \mathrm{mg} / \mathrm{kgbb}$ pada udema. Prosiding Rakernas dan Pertemuan Ilmiah Tahunan. Ikatan Apoteker Indonesia. Yogyakarta. 2016.

15. Devi BP, Boominathan R, Mandal SC. Antiinflammatory, analgesic and antipyretic properties of Clitoria ternatea root. Fitoterapia. 2003;74(4):345-9.

16. Al-Snafi AE. Pharmacological importance of Clitoria ternatea - a review. 2016;6(3):68-83.

17. Voon HC, Bhat R, Rusul G. Flower extracts and their essential oils as potential antimicrobial agents for food uses and pharmaceutical applications. Compr Rev Food Sci Food Saf. 2012; 11:34-55.

18. Widyarman AS, Drestia AM, Bachtiar EW, Bachtiar BM. The anti-inflammatory effects of glycerolsupplemented probiotic Lactobacillus reuteri on infected epithelial cells in vitro. Contemp Clin Dent. 2018;9(2):298-303.

19. Witedja U, Suwartini T, Prahasti AE, Widyarman AS. Comparing the Effectivities of Chitosan Citrate and Chitosan Acetate in Eradicating Enterococcus faecalis Biofilm. Sci Dent J. 2018;2(1):1-7. 
20. Naves P, del Prado G, Huelves L, Gracia M, Ruiz V, Blanco J, et al. Measurement of biofilm formation by clinical isolates of Escherichia coli is methoddependent. J Appl Microbiol. 2008;105(2):585-590.

21. Singh N, Patil A, Prabhune AA, Raghav M, Goel G. Diverse profiles of $\mathrm{N}$-acyl-homoserine lactones in biofilm forming strains of Cronobacter sakazakii. Virulence. 2017;8(3):275-281.

22. Iamsaard S, Burawat J, Kanla P, Arun S, Sukhorum W, Sripanidkulchai B, et al. Antioxidant activity and protective effect of Clitoria ternatea flower extract on testicular damage induced by ketoconazole in rats. J Zhejiang Univ Sci B. 2014;15(6):548-555.

23. Carranza FA, Newman MG, Takei HH, Klokkevold PR. Carranza's clinical periodontology. Saunders Elsevier: St. Louis, Mosby; 2006.

24. Pahune B, Niranjane K, Danao K, Bodhe M, Rokade V. Antimicrobial activity of Clitoria ternatea L. flower extract and use as a natural indicator in acid base titration. 2013;3(2):48-51.

25. Saptarini NM, Suryasaputra D, Nurmalia H. Application of Butterfly Pea (Clitoria ternatea Linn) extract as an indicator of acid-base titration. J Chem Phar Res. 2015;7(2):275-280.

26. Konczak I, Zhang W. Anthocyanins-more than nature's colours. J Biomed Biotechnol. 2004;2004(5):239-240.
27. Cisowska A, Wojnicz D, Hendrich AB. Anthocyanins as antimicrobial agents of natural plant origin. Nat Prod Commun. 2011;6(1):149-156.

28. Rabin N, Zheng Y, Opoku-Temeng C, Du Y, Bonsu E, Sintim HO. Agents that inhibit bacterial biofilm formation. Future Med Chem. 2015;7(5):647-671.

29. Kariu T, Nakao R, Ikeda T, Nakashima K, Potempa $\mathrm{J}$, Imamura $\mathrm{T}$. Inhibition of gingipains and Porphyromonas gingivalis growth and biofilm formation by prenyl flavonoids. J Periodontal Res. 2017;52(1):89-96.

30. Kamilla L, Mnsor SM, Ramanathan S, Sasidharan S. Antimicrobial activity of Clitoria ternatea (L.) Extracts. 2009;1:731-738.

31. Tarahovsky YS, Kim YA, Yagolnik EA, Muzafarov EN. Flavonoid-membrane interactions: Involvement of flavonoid-metal complexes in raft signaling. Biochim Biophys Acta BBA - Biomembr. 2014; 1838(5):1235-1246.

32. Zgurskaya HI, Löpez CA, Gnanakaran S. Permeability Barrier of Gram-Negative Cell Envelopes and Approaches To Bypass It. ACS Infect Dis. 2015;1(11):512-522.

33. Cushnie TPT, Lamb AJ. Antimicrobial activity of flavonoids. Int $\mathrm{J}$ Antimicrob Agents. 2005;26(5):343-356. 